\title{
Cluster approach to development of wine and gastronomy tourism in Volgograd region
}

\author{
Tatiana Kosulnikova ${ }^{1, *}$, Lidiya Sizeneva ${ }^{1}$, Dmitriy Sharapov ${ }^{1}$, Marina Semenova ${ }^{1}$ \\ ${ }^{1}$ FGBOU VO «Volgograd state agricultural university», Volgograd, Russia
}

\begin{abstract}
This article discusses the possibilities of grape growing and wine production industry in the Volgograd region development to increase the tourist attractiveness of the region. The article describes the soil and climate, historical, agricultural and technological and social and economic prerequisites for development of this branch. It was suggested to use the cluster approach, joining efforts of grape growers and wine producers, as well as scientific and educational, tourist and hospitability enterprises of the Volgograd region for rendering tourist and recreation services for the local residents, Russian and foreign guests of the city within the educational and production project of the Volgograd state agricultural university "Innovative village "Gornaya Polyana". The originality of suggestions is that the "Gornaya Polyana" is the unique educational, scientific and production center that not only provides the tourists with information on history, local traditions, technology and culture of alcohol drinking, but also suggests them tasting different varieties of grape and wine, working on vinelands, participating in wine festivals and thematic festivals; visiting and taking part in special exhibitions and meetings, workshop sessions and educational programs, joining the abilities of agricultural, wine, gastronomical, ethnographic, educational events and business tourism. The project suggests creating of the recreation and service areas such as: park area, pond, bath house at the water basin shore, recreation services, including the wine therapy and wine cosmetology; production and workshops, including wine production, willow weaving; leisure activities and services, accommodation means and other.The results of investigation should be used for solving the social and economic problems in the region due to development of non-agricultural activities at the rural area, such as: wine, gastronomical and ethnographical tourism.
\end{abstract}

\section{Introduction}

In our days, the grape and wine industry of the Russian Federation is highly profitable and socially important in the agricultural industry. Its products have got the high consumer demand.

The most favorable areas for grape growing are situated in the North Caucuses and in the Crimea - that is relatively narrow land area between the two seas - The Black Sea and the Caspian Sea, as well as small half island with area totally 25 thousand sq. km.

\footnotetext{
*Corresponding author: kosmosleta@ mail.ru
} 
The grape growing and wine production were brought to the Crimea and to the western coast of the Black sea by the Ancient Greeks, who settled the Black sea coast from V century B.C. The antic wine production tradition was continued by the Romans and the Byzantines (the least mostly in the Crimea). There were numerous Genoa settlements in the middle of the century in the Crimea and in the Taman; they brought Italian features in local wine production.

One more interesting grape growing and wine production center appeared more than one and half thousand years ago at the western Caucuses, in Dagestan, it was taken into possession at the Great Migration period by Turkic tribes of Khazars, who among the other activities, grew grapes at the districts of Derbent and Semender. But at the end of VII - VIII A.C., large army of Arabs from the south invaded to Dagestan, the Arabs spread the new religion - Islam. And Khazars, who continued to fight with the Arabs for centuries had to move center of their state to the Pryazovia to the Lower Don, the Lower Volga, where their last capital - the Itil city was constructed (now this place is called the Samosdelskoe gorodishche in the Astrakhan region). The culture bearers brought their knowledge and skills including the grape growing and wine production skills to the Lower Volga and the Lower Don.

The circumstantial evidence of this fact is the almost whole wine amphora of the Khazar time found in the southern part of Volgograd, it is now kept at the holdings of one of the museums. As for the Don region, traditions of grape growing and wine production developed are more successful than in the Lower Volga that fact is proved by numerous sources.

Moreover, many modern investigators see that traces of grape growing traditions of the Don Cossaks, who settled at the Tikhiy Don in the XV century, may have come from grape growing traditions of the early Middle Ages Khazars.

In the later period, the first written evidence of vinelands in Russia, planted near Astrakhan, was in 1613, when the Tsar Mikhail Fyodorovich ordered to find here the first Vineland for the tsar meals.

In 1656-1657, Astrakhan provided the tsar court with first batches of wine. In 1720, Peter I advised the Astrakhan governor to plant grapes and trees and herbs, brought form Persia.

The first attempts to make the commercial grape growing industry as the profitable independent agricultural branch were made in the German settlement in Sarepta, near the Tsaritsyn city at the end of XVIII - beginning of XX centuries.

From its beginning, the Sarepta grape growing industry was the combination of experience and traditions of Tsaritsyn, Astrakhan, European (German, Austrian, Hungarian, French), Caucasian, Crimea grape growing schools. [1]

In the XVIII century, S. Gmelin, A.I. Guldenstend, P.S. Pallas., I. I. Lepekhin, I. Falk, I. Georgy wrote about the Lower Volga grape growing. At the end of XVIII century, the grape growing and wine production developed to the north from Sarepta. For example, I. Georgy wrote about wine of Tsaritsyn governor, the hero of battle with Pugachev I.E. Tsypletev. The landowner Persidsky also had vinelands at the northern areas in Dubovka. In 1775, at the settlement Verkhnyaa Kulalinke (now it is the territory of the Kamyshin district), where the emigrants from Rein region were living, two gardens had up to 3000 grapes, planted by Peilers, born in Menzingen, who got in 1772200 poods of grape, but the taste was worse, then grape from Astrakhan. The wine, produced from it was of the light brown color and like French wine.

Grapes from Sarepta were sent to the tsar court in the buckets with grain. Time passed, and after some fails, the grape growing was spread in the settlements at the northern part of the modern Volgograd region, not only in German (Verkhnyaya and Nizhnyaya Dobrinka, Sevastyanovka, Sosnovka, Krasny Yar, as well as Verkhnyaya Kulalinka). 
We should also point out that the famous drink - Sarepta balsam, was founded in Sarepta, which later became the prototype of the famous Rizhsky balsam.

The first wine production plant was built in Sarepta 6 years later then the settlement was founded, and in 1771, it belonged to the religious community. In 1850, private balsam and vodka plant of F. Langerfeld was opened in Sarepta, and from 1860, it began to produce wine. Its raw material - the wine grape was bought at place - on the Don. The Sarepta vinelands in Sarepta, Shenbrune, Chapurnikovskaya balka were growing till $1970^{\text {th }}$ years.

It should be noted that founder of the Nikitskiy botanic garden Kh. Steven visited Sarepta at the beginning of the XIX century, and he saw the vinelands. The vinelands of Sarepta got some cultivars from the Crimea as well as from Europe.

Before revolution of 1917, there was growth of grape industry in many settlements of Lower Volga: Antipovka, Kamyshin, Usk-Kulalinka and others.

Today the officially recognized grape growing and wine production region "Lower Volga" is at the area from the town of Kamyshin of the Volgograd region in the North to the city of Astrakhan in the South. In 1948, A.I. Lubimov in his book "Grapes in the Stalingrad region" wrote on industrial grape growing "Kolkhoizes and sovkhozes of the Stalingrad region have all possibilities for extensive development of grapes. ... Vinelands of our region have good croup productivity". [2]

That is a real fact. For example, the Volga-Akhtuba plain is famous as the productivity value. The fertile ground, lots of sunlight give the plain features of the most favourable agricultural area of the country, but only with irrigation. [3]

The object of the scientific work is to detect the perspectives of development for grape growing, wine production industries and wine tourism in the Volgograd region for increasing the tourist attractiveness of the region.

To achieve this object, we should set and resolve the tasks as following:

- detect the soil and climate, historical, agricultural and technological as well as social and economic prerequisites for wine and gastronomical tourism development;

- analyze the possibilities for development of wine and gastronomical tourism in the Volgograd region on the basic of statistical data;

- develop the project suggestions for forming of wine and gastronomical territory at the cluster principle at the UNPTs "Gornaya Polyana" and introduce providing of tourist and recreation services to the local residents, Russian and foreign guests.

The object of investigation is wine and gastronomical tourism at the rural territories of the Volgograd region. The subject of investigation is the cluster approach in development of tasting tourism of the Volgograd region at the UNPTs "Gornaya Polyana".

\section{Materials and methods}

We used the data of statistical reports of Ministry of agriculture of the Russian Federation, data from published documents on grape growing and wine production system of the Lower Volga and the Southern Federal district in the historical retrospective view, as well as results of scientific investigations of A.S. Ovchinnikov, V.V. Borodychev, P.A. Sheppel, N.V. Kurapina and others.

We made the comparative and system analyses of the respective specifications. Data for analyses were selected on the system basis considering set of uniform conditions.[4] Processing and analyses of statistical and experimental data are proved by experts opinion in the grape growing and the wine production field, as well as representatives of tourist branch in the city of Volgograd: I. Yu. Podkovyrova, P.K. Zamanidi, S.E. Guseva, D.E. Guseva, V.G. Zimovets, I.N. Dregval, O.I. Chebotareva et. al.

The climate of the most grape growing areas in Russia is mostly extremely continental with hot summers and severe winters. Favorable climate for grape growing are areas with 
average amount of active temperatures 4000-4500 degrees. At the north border of the industrial grape growing (Novocherkassk - Volgograd) the amount of active temperatures is 3300 degrees.

For the last three decades, the basic conditions for successful development of industrial grape growing at the Lower Volga were achieved mostly due to development of the covered grape growing, making of new varieties and forms of grape with the ultra-early and early ripening; breeding more winter and frost proof varieties, considering Russian climate, as well as new technologies. At present moment the area of grape planting in the Volgograd region doesn't exceed 0.5 thousand hectares and gross grape collection exceeds 60 thousand quintals at the crop yielding at about $15 \mathrm{t} / \mathrm{ha}$ and taking steady 1-2 place at the Southern Federal district (table 1-4).

In the Volgograd region, there are about 15 specialized facilities in Dubovsky, Sredneakhtubinsky, Gorodishencky, Kamyshinsky, Urupinsky districts that produce grape for earing and wine producing, young plants, as well as wine. Volgograd businessmen and businesswomen are ready to change the imported wine at the local market for domestic product and promise to drive the Europe and Western world wine from the market. [5]

Table 1. Basic data for the grape planting at the facilities of different categories (2014).

\begin{tabular}{|l|c|c|c|}
\hline \multicolumn{1}{|c|}{ Regions } & \multicolumn{1}{|c|}{$\begin{array}{c}\text { Yielding area. } \\
\text { thousand ha }\end{array}$} & $\begin{array}{c}\text { Total grape yield. } \\
\text { Thousand } \\
\text { quintals }\end{array}$ & $\begin{array}{c}\text { Grape yield. quintals } \\
\text { from 1 hectare of } \\
\text { harvested acreage }\end{array}$ \\
\hline The Russian Federation & 68.68 & 5285.5 & 75.9 \\
\hline Southern Federal district & 23.27 & 2379.8 & 96.1 \\
\hline Volgograd region & 0.26 & 39.9 & 151.7 \\
\hline $\begin{array}{l}\text { Volgograd region place at } \\
\text { the ranking }\end{array}$ & $3^{\text {rd }}$ place in YUFO & $3^{\text {rd }}$ place in YUFO & $1^{\text {st }}$ place in YUFO \\
\cline { 2 - 4 } & $9^{\text {th }}$ place in RF & $8^{\text {th }}$ place in RF & $7^{\text {th }}$ place in RF \\
\hline
\end{tabular}

Table 2. Yielding area of grapes plants at the facilities of different categories (thousand ha).

\begin{tabular}{|l|c|c|c|c|}
\hline \multicolumn{1}{|c|}{ Regions } & $\mathbf{2 0 1 5}$ & $\mathbf{2 0 1 6}$ & $\mathbf{2 0 1 7}$ & $\mathbf{2 0 1 8}$ \\
\hline THE RUSSIAN FEDERATION & 70.7 & 74.4 & 74.8 & 75.1 \\
\hline Southern federal district & 44.8 & 47.0 & 46.9 & 46.2 \\
\hline The Republic of Adygeya & 0.1 & 0.1 & 0.1 & 0.1 \\
\hline The Republic of Kalmykia & N/A & N/A & N/A & N/A \\
\hline The Republic of Crimea & 14.1 & 16.8 & 16.1 & 15.9 \\
\hline Krasnodar Krai & 21.3 & 20.8 & 21.5 & 21.7 \\
\hline Astrakhan region & 0.2 & 0.1 & 0.1 & 0.1 \\
\hline Volgograd region & 0.4 & 0.5 & 0.5 & 0.5 \\
\hline Rostov region & 3.3 & 3.5 & 3.6 & 3.2 \\
\hline Sevastopol & 5.4 & 5.2 & 5.0 & 4.8 \\
\hline
\end{tabular}

Table 3. Gross collection of grape at the facilities of different categories (thousand ha).

\begin{tabular}{|l|c|c|c|c|}
\hline \multicolumn{1}{|c|}{ Regions } & $\mathbf{2 0 1 5}$ & $\mathbf{2 0 1 6}$ & $\mathbf{2 0 1 7}$ & $\mathbf{2 0 1 8}$ \\
\hline THE RUSSIAN FEDERATION & 5199.8 & 6013.3 & 5800.8 & 6277.4 \\
\hline Southern federal district & 3000.3 & 3623.1 & 3310.7 & 3668.8 \\
\hline The Republic of Adygeya & 6.8 & 9.7 & 9.6 & 27.1 \\
\hline The Republic of Kalmykia & 4.0 & 3.4 & 1.7 & 1.9 \\
\hline The Republic of Crimea & 649.8 & 643.3 & 707.8 & 801.0 \\
\hline Krasnodar Krai & 1827.9 & 2396.4 & 2019.9 & 2175.9 \\
\hline Astrakhan region & 10.4 & 13.4 & 19.7 & 21.2 \\
\hline Volgograd region & 62.6 & 67.6 & 69.0 & 66.2 \\
\hline Rostov region & 170.8 & 181.8 & 174.6 & 280.4 \\
\hline Sevastopol & 268.0 & 307.5 & 308.4 & 295.2 \\
\hline
\end{tabular}


Table 4. Grape yields at the facilities of different categories (Quintals from 1 hectare of harvested acreage).

\begin{tabular}{|l|c|c|c|c|}
\hline \multicolumn{1}{|c|}{ Regions } & $\mathbf{2 0 1 5}$ & $\mathbf{2 0 1 6}$ & $\mathbf{2 0 1 7}$ & $\mathbf{2 0 1 8}$ \\
\hline THE RUSSIAN FEDERATION & 77.8 & 86.6 & 84.9 & 91.9 \\
\hline Southern federal district & 69.9 & 81.2 & 75.7 & 84.3 \\
\hline The Republic of Adygeya & 73.4 & 106.5 & 104.7 & 291.1 \\
\hline The Republic of Kalmykia & 129.3 & 123.2 & 74.6 & 74.5 \\
\hline The Republic of Crimea & 49.8 & 44.2 & 53.0 & 55.3 \\
\hline Krasnodar Krai & 88.3 & 114.9 & 93.6 & 101.8 \\
\hline Astrakhan region & 69.7 & 95.3 & 141.3 & 154.6 \\
\hline Volgograd region & 152.0 & 146.3 & 147.6 & 146.8 \\
\hline Rostov region & 52.9 & 54.0 & 55.4 & 122.7 \\
\hline Sevastopol & 51.1 & 59.5 & 62.9 & 62.9 \\
\hline
\end{tabular}

By the result of analyses held by the authors, we can declare that grape growing and wine production in the Volgograd region have got good opportunities, with some advantages and disadvantages comparing with the neighboring Southern Russian regions.

\section{The results and discussions}

One of the important factors for acceleration of this industry development is designing of modern technologies, which, considering the climatic conditions of the region allow getting stable high crops of the excellent quality. [6] Experience of the advanced facilities, role of science, contribution of crop breeders from the Volgograd branch of FGBNU "VNIIGiM named after A.N. Kostiakov', FGBOU VO Volgograd GAU, where investigations were held to develop technologies of grape growing and grape young plants that meet the requirements of local ecological conditions, come to the fore.

The educational, scientific and production center "Gornaya Polyana" of the Volgograd state agricultural university is a biggest scientific and production facility with experimental wine land with different varieties and hybrid forms for the wine producing territory "the Lower Volga". In 2017, in the territory of UNPTs "Gornaya Polyana" was planted the experimental Vineland with 11 varieties of grapes to produce wine and for eating. Managers of the Volgograd State Agricultural University plan to construct wine production plant for producing and bottling of excellent quality wines, made of own varieties.

It is commonly known that places with wine require tourists. It should be mentioned that wine tourism is the joining factor for development of different forms of tourism: gastronomical, ethnographic, agricultural, rural, events and business. [7]

During the excursion tour, the tourist of the wine tourism industry get acquaint with history, technology and culture of alcohol drinks consumption. Wine tourist gives the possibility of visiting and trying to do the agricultural work at the wine areas; tasting the local grape varieties; learning the alcohol drinks production technologies at the production facility; learning the wine production history, visiting special museums; visiting the tasting rooms and basements; taking part in wine festivals and thematic events; visiting and taking part in special exhibitions and meetings. [8]

Professional union of grape growers of the region became of the primary need. At the result the Grape breeding center of the Volgograd GAU, which has the great collection of varieties from all over the world became the center of grape growing association of the Lower Volga.

That was the important event, certifying increasing of wine production plants number, necessity to decrease risks, product diversification, development of general marketing tools for development of wine brand of the region, organization of wine festivals and other 
events, as well as necessity to create governmental relations of Volgograd grape growers in the region and outside of it. [9]

Thus, at present stage of grape growing and wine production development, we need to have cluster approach in the region, joining round one core the system of interconnected companies and organizations, with value as the whole exceeding the value of components.[10] Joining of efforts of those who produce grapes, planting material and wine and scientific and educational institutions of tourism and hospitality on the basis of cluster approach is necessary in order to create and develop of the high technological brunch to provide the region and the country with native products of grape growing industry.

The basic principles of the cluster are mutual understanding and collaboration of all members of the process; equal status and share of all members of the constructive dialog; voluntariness to select forms of collaboration; manual providing information and fulfillment of assumed obligations according to economic contracts, concluded between the cluster members and so on.

In the whole world, grape growing is directly connected with tourism, with service and hospitality.[11] And the cluster creates the standards for providing service to the clients, production of high quality tourist services, resolves the issues on ways to join the necessity of creation the united brand and service department, communication strategies of interrelations with clients and partners, authorities and competitors.

Almost one and only channel of distribution, especially at the initial stage of development of wine production plants are tasting rooms. The main source of profit is selling directly to the client in the tasting rooms (selling in the tasting rooms make average $90 \%$ ). The income from tasting rooms directly depends on cooperation with tourist companies. [12]

At the initial state of vital cycle during creation of production process, the priority is given to marketing and creation of brand. The main way of promoting among the tourists is the buzz marketing, as main clients are local residents, who tell to their relatives and friends.

As the production develops, the wine production plants expend the suggestions, shifting attention from the product to the new services for the guests. For example, they increase the number of the tasting rooms with luxury food, books and different items, connected with wine, in order to create more scenic beauty they make ponds and facilities to have lunch in the fresh air, and they also build small hotels of the "bed \&breakfast" type. At this state the wine production industry gets the clients, who are experts in the wine industry. [13]

Now the wine production plant has got the fixed excursion process: the main attention is given to showing the production process, from grape growing to finishing designing of the finished product. The excursions finish up at the tasting rooms, where visitors can taste wine, whose production process they have just seen and also buy it. We need not only provide the excursion program, but orient to the target consumer and make such programs, which meet the theme of tourist products and standards, told by the tourist operators. [14]

It should be mentioned that wine and gastronomical tourism, as it develops, changes the focus among the other to the educational and events themes to meet the requirements of the certain segment of tourists. Creation of new events for corporative segment MICE requires making meeting rooms, exhibition areas and development of infrastructure in general. [15] As the organizer of such events the Volgograd state agricultural university is the best.

It order to demonstrate the best practice of promoting the new directions into market economy by training of personnel and mutual profitable collaboration of science, production and business the university developed the product of regional educational and productive center "Innovative village "Gornaya Polyana".

Within this innovative and investment project, considering the Russian best practice, we suggest to create at the UNPTs 'Gornaya Polyana' the wine and gastronomical territory on 
the cluster basis and introduce providing tourist and recreation services to the local residents, Russian and foreign guests of the city. The theme of local (Southern Russian) wine production, including the wine tourism, is able to become one of the leading at the designed project and the project suggestions introduce creation of the recreation and service areas as follows:

1) Production facilities and workshops: production of wine, kumys, kvas, with tasting; willow weaving; apothecary garden, packets packing of herbs and teas; bee yard; mill house, bakery; smoke house; pickling and conservation of vegetables and fruits; cheese factory and butter factory; pottery; blacksmith shop; souvenir and agricultural products shop;

2) The park and recreation area: "dry fountain"; area of the rope and trampoline center; climbing wall; area for riding scooters, bicycles, ski; sport grounds for mini football, volleyball and other mass games; pound with fountain and night illumination; equipment for barbeque zone, hiring of scooters and boats; construction of sheds and summer café with ecological products, fish breeding in the pond; cultivation of water plants and lilies; organization area for fishing, in winter time organization of rinks;

3 ) recreation services: wine therapy and ecological cosmetology; herbal teas from the apothecary garden; different types of massage; treatment with the help of honey, kumys, goat's milk; aromatherapy; bath house at the water basin shore with the platform for jumping into the water;

4) leisure activities and services: riding horses and in carriage; teambuilding; birthday parties, weddings; staff parties; concerts indoors and outdoors; excursions for different groups of clients; equipping of areas for taking pictures, photo and video services; beach services; laundry; parking and car washing;

5) Business events: exhibition hall, lodging facilities and catering facilities: guest houses; tent camp (if applicable); café with banquet hall, business center for work of guests and holding of educational seminars, lectures and workshop sessions.

Table 5. Economical indexes of the project.

\begin{tabular}{|c|c|c|c|c|c|c|c|}
\hline \multirow[b]{2}{*}{$\begin{array}{c}\text { Item } \\
\text { No }\end{array}$} & \multirow{2}{*}{$\begin{array}{l}\text { Name of } \\
\text { target } \\
\text { indicators }\end{array}$} & \multirow{2}{*}{$\begin{array}{c}\text { Units of } \\
\text { measurement }\end{array}$} & \multicolumn{5}{|c|}{ Years } \\
\hline & & & $\begin{array}{l}2020- \\
2021\end{array}$ & $\begin{array}{l}2021- \\
2022\end{array}$ & $\begin{array}{l}2022- \\
2023\end{array}$ & $\begin{array}{l}2023- \\
2024\end{array}$ & Main results \\
\hline 1 & $\begin{array}{l}\text { Construction } \\
\text { of tourist and } \\
\text { recreation } \\
\text { facilities }\end{array}$ & $\begin{array}{l}\text { Expenses in } \\
\text { mln. rubles }\end{array}$ & 350 & 100 & 25 & 25 & $\begin{array}{l}\text { Production and } \\
\text { social infrastructure } \\
\text { facilities; guest } \\
\text { houses, catering } \\
\text { facilities, sport } \\
\text { infrastructure } \\
\text { facilities }\end{array}$ \\
\hline \multirow{3}{*}{2} & \multirow{3}{*}{$\begin{array}{l}\text { Organization } \\
\text { of services } \\
\text { on the basis } \\
\text { of recreation } \\
\text { and tourist } \\
\text { unit } \\
\text { 'Gornaya } \\
\text { Polyana' }\end{array}$} & $\begin{array}{l}\text { Expenses in } \\
\text { mln. rubles }\end{array}$ & - & 6.3 & 17.5 & 50.4 & \multirow{3}{*}{$\begin{array}{l}\text { Providing of tasting } \\
\text { and agricultural } \\
\text { tourism services } 5 \\
\text { organization of } \\
\text { events; excursion } \\
\text { services, recreation }\end{array}$} \\
\hline & & $\begin{array}{c}\text { Number of } \\
\text { tourists }\end{array}$ & - & 3000 & 5000 & 12000 & \\
\hline & & $\begin{array}{l}\text { Income in } \\
\text { mln.rubles }\end{array}$ & - & 9 & 25 & 72 & \\
\hline
\end{tabular}




\section{Summary}

Art present moment, the grape growing and wine production industry of the Russian Federation is high profitable and socially important at the agricultural industry. Its products are in great demand.

Nowadays, the area of grape planting in the Volgograd region doesn't exceed 0.5 thousand hectares, and gross yield of grapes is more than 60 thousand quintal at the crop capacity at about 15 tons per hectare, taking the steady $1-2^{\text {nd }}$ place at the Southern Federal district.

In the Volgograd region, there are at about 15 specialized facilities in Dubovsky. Sredneakhtubinsky, Gorodishencky, Kamyshinsky, Urupinsky districts, who produce grape for earing and wine producing, young plants, as well as wine. Volgograd businessmen and businesswomen are ready to change the imported wine at the local market for domestic product and promise to drive the Europe and Western world wine from the market.

In order to create and develop the high technological branch to provide the grape growing industry products to the region, we need to have cluster approach, joining efforts of grape and wine producers and scientific and educational institutions, tourism and hospitality companies on the basis of cluster approach.

Within the educational and production project of the Volgograd State Agricultural University "Innovation village 'Gornaya Polyana', considering the best Russian practices, we suggest to introduce tourist and recreation services to the local residents, Russian and foreign guest of the city. The perspectives for development of wine and gastronomical as well as rural tourism in general for Volgograd state agricultural university are quite real and wide ranging.

The University is interested in development of agriculture of the whole region, collaboration with science, business and authorities. But in future the role of nonagricultural types of activities would definitely increase. The rural tourism, joining other types of tourism, will take special place, as it will allow organizing working places and increasing income of not only businessmen, farm owners, who invite tourists, but will also make working places in joining sphere of hospitality, and would contribute to branding of the territory and promoting of new tourist destinations.

\section{Reference}

1. V.N. Medvedev, Scientific yearbook "Strezhen" (VolSU, Volgograd, 2001)

2. A.I. Lyubimov, Grapes in the Stalingrad region (Regional Publishing House, Stalingrad, 1948)

3. A.V. Nemchenko, T.A. Dugina, E.A. Likholetov, A.V. Malofeev, A.A. Likholetov, International Journal of Economics and Financial Issues 6(2), 207-211 (2016)

4. A.V. Dyachenko, T.L. Kosulnikova, L.A. Sizeneva, Z.M. Kazieva, Service in Russia and abroad 13.1(83), 19-34 (2019) DOI: 10.24411/1995-042X-2019-10102

5. R.S. Shepitko, A.V. Nemchenko, T.A. Dugina, E.A. Likholetov, Region economy 4(44), 275-288 (2015) DOI: 10.17059/2015-4-22

6. A.V. Nemchenko, A.V. Malofeev, Bulletin of Agricultural Science 3(78), 114-121 (2019) DOI: 10.15217/issn2587-666X.2019.3.114

7. A. Nicolosi, L. Cortese, F. Saverio Nesci, D. Privitera, Procedia - Social and Behavioral Sciences 22310, 662-667 (2016)

8. W. Frost, J. Frost, P. Strickland, J. Smith Maguire, International Journal of Hospitality Management 87, 102460 (2020) 
9. L.A. Sizeneva, A.V. Dyachenko, T.L. Kosulnikova, International Journal of Engineering and Technology 7, 502 (2018)

10. D.G. Dontsov, N.G. Yushkova, E.G. Gushchina, IOP Conference Series: Materials Science and Engineering, 032055 (2018) DOI: 10.1088/1757-899X/463/3/032055

11. T.V. Thanh, V. Kirova, Journal of Business Research 83, 30-37 (2018)

12. J. Martins, R. Gonçalves, F. Branco, L. Barbosa, M. Bessa, Journal of Destination Marketing \& Management 6(2), 103-109 (2017)

13. Sh. Xu, C. Barbieri, D. Anderson, Y. Leung, S. Rozier-Rich, Tourism Management 55, 276-286 (2016)

14. L.A. Sizeneva, Service in Russia and abroad 12.3(81), 90-111 (2018) DOI: 10.24411/1995-042X-2018-10307

15. A.V. Dyachenko, T.L. Kosulnikova, N.N. Balashova, L.A. Sizeneva, I.V. Dneprovskaya, Lecture Notes in Networks and Systems 87, 460-471 (2020) DOI: 10.1007/978-3-030-29586-8_53 